OPEN ACCESS

Edited by:

Marian Brestic,

Slovak University of Agriculture,

Slovakia

Reviewed by:

Oksana Sytar,

Slovak University of Agriculture,

Slovakia

Fernando José Cebola Lidon, Faculdade de Ciências e Tecnologia da Universidade Nova de Lisboa,

Portugal

${ }^{*}$ Correspondence:

Fei Liu

liufei888@163.com

Specialty section:

This article was submitted to

Plant Abiotic Stress,

a section of the journal

Frontiers in Plant Science

Received: 28 February 2018 Accepted: 13 April 2018

Published: 04 May 2018

Citation:

Zhou $X$, Sun C, Zhu P and Liu F (2018) Effects of Antimony Stress on Photosynthesis and Growth of Acorus

calamus. Front. Plant Sci. 9:579.

doi: 10.3389/fpls.2018.00579

\section{Effects of Antimony Stress on Photosynthesis and Growth of Acorus calamus}

\author{
Xiujie Zhou, Chongyu Sun, Pengfei Zhu and Fei Liu* \\ School of Life Sciences, Huaibei Normal University, Huaibei, China
}

This study was aimed to explore that effects of $\mathrm{Sb}$ on physiological parameters of Acorus calamus and the possibility of using $A$. calamus as a remediation plant. $A$. calamus potted experiments were conducted using different concentrations $(0,250$, 500, 1000, and $2000 \mathrm{mg} / \mathrm{kg}$ ) of antimony potassium tartrate $\left(\mathrm{Sb}^{3+}\right.$ ) (marked as $\mathrm{CK}$, $T_{1}, T_{2}, T_{3}$, and $T_{4}$, respectively) and potassium pyroantimonate $\left(\mathrm{Sb}^{5+}\right)$ (marked as $\mathrm{CK}, \mathrm{T}_{1}^{\prime}, \mathrm{T}_{2}^{\prime}, \mathrm{T}_{3}^{\prime}$, and $\mathrm{T}_{4}^{\prime}$, respectively). The effects of $\mathrm{Sb}$ stress $\left(\mathrm{Sb}^{3+}\right.$ and $\left.\mathrm{Sb}^{5+}\right)$ on leaf photosynthetic pigments, biomass, photosynthetic characteristics and chlorophyll fluorescence parameters of potted $A$. calamus were studied. With the rise of $\mathrm{Sb}^{3+}$ concentration from $T_{1}$ to $T_{4}$, the leaf pigment contents (chlorophyll $a, b$, carotenoid), plant height, dry weight, net photosynthetic rate (Pn), stomatal conductance (Gs), evaporation rate (E), PSII maximum photochemical efficiency (Fv/Fm), and PSIl electron transfer quantum yield rate (ФPSII) of $A$. calamus all reduced, while intercellular $\mathrm{CO}_{2}$ concentration $(\mathrm{Ci})$ significantly increased. The reduction of $\mathrm{Pn}$ was mainly induced by non-stomatal limitation. Chlorophyll a/b ratio increased significantly versus the control, while carotenoid/chlorophyll ratio (Car/Chl) first decreased and then increased. The leaf Chl a, Chl b, Car, plant height, dry weight, Pn, Gs, E, Fv/Fm, and ФPSIl all maximized in $\mathrm{T}^{\prime}{ }_{1}(250 \mathrm{mg} / \mathrm{kg})$, but were not significantly different from the control. As the $\mathrm{Sb}^{5+}$ concentration increased from $\mathrm{T}_{2}^{\prime}$ to $\mathrm{T}_{4}^{\prime}$, the above indices all decreased and were significantly different from the control. Moreover, intercellular $\mathrm{CO}_{2}$ concentration (Ci) decreased significantly. The reduction of $\mathrm{Pn}$ was caused by non-stomatal limitation, indicating the mesophyll cells were damaged. The Car/Chl ratio was stable within 0$500 \mathrm{mg} / \mathrm{kg} \mathrm{Sb}$, but decreased in $\mathrm{T}_{3}$ and $\mathrm{T}_{4}$, and rose in $\mathrm{T}_{3}{ }_{3}$ and $\mathrm{T}_{4}{ }_{4}$. After $\mathrm{Sb}^{3+}$ and $\mathrm{Sb}^{5+}$ treatments, translocation factor varied $19.44-27.8$ and $19.44-24.86 \%$, respectively. In conclusion, different form $\mathrm{Sb}^{3+}$ treatment, $\mathrm{Sb}^{5+}$ treatment showed a Hormesi effect, as low-concentration treatment promoted $A$. calamus growth, but high-concentration treatment inhibited its growth. The two forms of $\mathrm{Sb}$ both caused unfavorable effects on $A$. calamus, but the seedlings did not die and were modestly adaptive and Sbaccumulative. A. calamus, which is easily maintained and cultivated, can serve as a good candidate for phytoremediation of water contaminated with Sb.

Keywords: antimony, Acorus calamus, photosynthetic pigment, photosynthesis, biomass, phytoremediation 


\section{INTRODUCTION}

Antimony (Sb) is a ubiquitous trace element in the environment and a global pollutant and has been included as a priority pollutant by United States Environmental Protection Agency owing to its latent toxicity and carcinogenicity (Liu et al., 2013; Corrales et al., 2014). Some pollutants of heavy metal come from a variety of natural and man-made sources (Sytar et al., 2016). However, extensive use of Sb compounds has discharged numerous $\mathrm{Sb}$ into waters, soils and air, causing severe $\mathrm{Sb}$ pollution. For instance, the soil $\mathrm{Sb}$ concentrations in a $\mathrm{Sb}$ mining area of Italy were $19-4400 \mathrm{mg} \cdot \mathrm{kg}^{-1}$, and the root $\mathrm{Sb}$ concentrations of Pistacia lentiscus were $0.46-22.3 \mathrm{mg} / \mathrm{kg}$ (Cidu et al., 2014). The soil and plant $\mathrm{Sb}$ concentrations in a tin deposit mountain of Hunan, China, were $10-2159$ and $143.7 \mathrm{mg} \cdot \mathrm{kg}^{-1}$, respectively (Wang et al., 2010; He et al., 2012), which interfered with plant growth and human health (Liu et al., 2010; Fu et al., 2011; Li et al., 2017). Thus, Sb pollution cannot be ignored.

$\mathrm{Sb}$ mainly exists as $\mathrm{Sb}^{+3}$ and $\mathrm{Sb}^{5+}$ in the environment, and its toxicity is related with the concentration and existing form (Huang et al., 2012). Generally, $\mathrm{Sb}^{3+}$ is more toxic than $\mathrm{Sb}^{5+}$. $\mathrm{Sb}$ is not a necessary element for plant growth (Filella et al., 2002, 2009), but can yet be absorbed by plants. The Sb absorbing ability differs among plant species (Shtangeeva et al., 2012). The Sb compounds affect the electron transfer, photosystem II carbonic anhydrase activity and the chloroplast glutathione reductase during photosynthesis (Karacan et al., 2016).

$\mathrm{Sb}$ existing as solutions in soils can be easily absorbed by plants, which would induce toxic effects to plants, including growth retardation, photosynthesis repression, and reduced synthesis of some metabolites (Feng et al., 2013). As reported, transport proteins are critical in the $\mathrm{Sb}$ absorption by plants. $\mathrm{Sb}^{3+}$ is absorbed by plants through transport proteins (NIP1 group) (Kamiya and Fujiwara, 2009). Under $\mathrm{Sb}^{5+}$ stress, the biomass of maize was significantly reduced (Cai et al., 2016). Ji et al. (2017) used a synchrotron of X-ray absorption near-edge structure to analyze the forms of $\mathrm{Sb}$ in ryegrass in vivo. In a soil-plant system, Arbuscular mycorrhizal fungi can relieve the $\mathrm{Sb}$ toxicity to plants (Wei et al., 2016; Pierart et al., 2017). Owing to the similar chemical properties between $\mathrm{Sb}$ and $\mathrm{As}$, the $\mathrm{Sb}$ absorption mechanisms by plants can be deduced from those of As. However, the response mechanism to Sb stress is still unclear.

Acorus calamus is an adaptive and wet/drought-resistant tall perennial herb capable of purifying wastewater and relieving water eutrophication. A. calamus has been widely used in urban ecological park construction, and has been adopted in recent 20 years to absorb N, P and heavy metals from polluted waters, which shows its high eco-environmental values.

The action of Sb on plants would induce complex effects. $\mathrm{Sb}$ at low concentration could modestly promote the growth of some plant species, and its toxicity only acts at high concentrations. However, the mechanisms how A. calamus responds to different forms of $\mathrm{Sb}$ are yet unclear. This study was aimed to explore (i) the effects of $\mathrm{Sb}$ on physiological parameters of A. calamus, including photosynthesis efficiency, intercellular $\mathrm{CO}_{2}$ concentration, and photosystem action sites; (ii) the poisoning mechanism of $\mathrm{Sb}$ to A. calamus, especially the photosynthesis system; (iii) the possibility of using A. calamus to repair heavy $\mathrm{Sb}$ pollution areas. This study will scientifically underlie the introduction and application of Sb-resistant plants, and offer theoretical references for further exploring the ecological values of A. calamus.

\section{MATERIALS AND METHODS}

\section{Materials}

The study site was located in a greenhouse of Huaibei Normal University, Anhui province, China. The indoor temperature (18$28^{\circ} \mathrm{C}$ ) was favorable for spring sowing and the growth of winter crops. A. calamus seedlings were purchased from a commercial supplier. L-Antimony Potassium Tartrate (III) $\left(\mathrm{C}_{8} \mathrm{H}_{4} \mathrm{~K}_{2} \mathrm{O}_{12} \mathrm{Sb}_{2}\right)$ and Potassium acid pyroantimonate $(\mathrm{V})\left(\mathrm{K}_{2} \mathrm{H}_{2} \mathrm{Sb}_{2} \mathrm{O}_{7} \cdot 4 \mathrm{H}_{2} \mathrm{O}\right)$ were both analytically pure (Shanghai Sinopharm Group Co., Ltd.). A. calamus was planted in 30 round pots (upper and lower inside diameters $=20$ and $18 \mathrm{~cm}$, respectively; height $=16 \mathrm{~cm}$ ).

\section{Methods}

Each pot was each filled with $10 \mathrm{~kg}$ of air-dried soil (3-mm sieve), which was mixed evenly. Then the pots were added with different concentrations $(0,250,500,1000$, and $2000 \mathrm{mg} / \mathrm{kg})$ of $\mathrm{C}_{8} \mathrm{H}_{4} \mathrm{~K}_{2} \mathrm{O}_{12} \mathrm{Sb}_{2}\left(\mathrm{Sb}^{5+}\right.$, marked as $\mathrm{CK}, \mathrm{T}_{1}, \mathrm{~T}_{2}, \mathrm{~T}_{3}$, and $\mathrm{T}_{4}$, respectively) or $\mathrm{K}_{2} \mathrm{H}_{2} \mathrm{Sb}_{2} \mathrm{O}_{7} \cdot 4 \mathrm{H}_{2} \mathrm{O}\left(\mathrm{Sb}^{3+}\right.$, marked as $\mathrm{CK}, \mathrm{T}^{\prime}{ }_{1}$, $\mathrm{T}_{2}^{\prime}{ }_{2}, \mathrm{~T}^{\prime}{ }_{3}$, and $\mathrm{T}_{4}^{\prime}$, respectively). Totally 10 treatments were set. All experiments were performed in triplicate. The growing plants were irrigated with distilled water if necessary. After 60 days, samples were collected, crushed and sent for measurement of $\mathrm{Sb}$ concentrations.

\section{Data Measurement and Calculation}

The net photosynthetic rate $\left(\mathrm{P}_{\mathrm{n}}\right)$, stomatal conductance $\left(\mathrm{G}_{\mathrm{s}}\right)$, evaporation rate $(\mathrm{E})$, and intercellular $\mathrm{CO}_{2}$ concentration (Ci) per unit leaf area in calamus leaves under different treatments were measured on a portable Licor-6400XT photosynthesis tester (United States). Photosynthesis was tested in open air and at light intensity $800 \mathrm{~mol} \cdot \mathrm{m}^{-2} \cdot \mathrm{s}^{-1}$, $\mathrm{CO}_{2}$ concentration $=360 \mu \mathrm{mol} \cdot \mathrm{mol}^{-1}$ on sunny days during 9:00-11:30 am. After $30 \mathrm{~min}$ of dark adaptation, a saturation pulse induces maximal fluorescence yield $(\mathrm{Y})$, and $\mathrm{Y}$ is given by a portable adjustable chlorophyll fluorescence device (Mini-Pam, Germany). Fluorescence induction curves were detected using the built-in automatic light source. The fiber optics are held at short distance (ca. $10 \mathrm{~mm}$ ) to a leaf of A. calamus, and the START-key is pressed. The real quantum yield of PSII (ФPSII) is proceeding automatically within seconds.

The leaves with the same positions and maturity degrees between photosynthesis and chlorophyll fluorescence were collected and their chlorophyll concentrations were detected on a UV-2550 ultraviolet-visible (UV-vis) spectrophotometer (Shimadzu, Japan) in the laboratory. Each experiment involved three to five leaves, and each leaf was measured three times. The optical densities (ODs) at 663, 645, and $470 \mathrm{~nm}$ were measured. Chlorophyll concentrations were expressed as the mean in the unit of $\mathrm{mg} \cdot \mathrm{g}^{-1} \cdot \mathrm{FW}$. Before measurement of biomass 
and $\mathrm{Sb}$ concentrations, green was removed by oven-drying the seedlings at $105^{\circ} \mathrm{C}$ for $30 \mathrm{~min}$, followed by drying at $70^{\circ} \mathrm{C}$ and weighing. The Sb concentrations in the underground and aboveground parts were measured on a WF-210 atomic absorption spectrophotometer (Beifen-Ruili Instrument Co., Ltd., China). The Sb translocation factor (TF\%) was computed as aboveground $\mathrm{Sb}$ concentration / underground Sb concentration.

\section{Statistic Analysis}

All data were expressed as the average of three repeated measurements. In one-way analysis of variance (ANOVA), the homogeneity of variance was compared multiple times using the least significant difference (LSD) method. In case of heterogeneity, Dunnett's T3 was used to test the difference of the same index among different treatments. Statistical analysis and plotting were performed on SPSS 20.0 and SigmaPlot 12.5 , respectively. Data were expressed as mean \pm standard deviation (SD).

\section{RESULTS AND ANALYSIS}

\section{Effects of Sb Stress on Leaf Pigment Concentrations}

The leaf photosynthesis pigment concentrations after different treatments $\left(\mathrm{Sb}^{3+}\right.$ and $\left.\mathrm{Sb}^{5+}\right)$ are listed in Table 1. Compared with $\mathrm{CK}$, the contents of leaf chlorophylls $\mathrm{a}, \mathrm{b}$, and $\mathrm{a}+\mathrm{b}(\mathrm{Chl}$ $\mathrm{a}, \mathrm{Chl} \mathrm{b}$, and $\mathrm{Chl} \mathrm{a}+\mathrm{b}$ ), and carotenoid (Car) all significantly decreased after $\mathrm{Sb}^{3+}$ treatments $\left(\mathrm{T}_{1}, \mathrm{~T}_{2}, \mathrm{~T}_{3}\right.$, and $\left.\mathrm{T}_{4}\right)$ and were all negatively correlated with the $\mathrm{Sb}^{3+}$ concentrations $\left(R^{2}=-0.8076,-0.8044,-0.8119\right.$ and -0.8116 , respectively; (all $P<0.01)$. However, Chlorophyll a/b ratios $(\mathrm{Chl} \mathrm{a} / \mathrm{b})$ all increased significantly, while the carotenoid/chlorophyll ratios (Chl/Car) decreased from 0.23 to 0.18 . The $\mathrm{Chl}$ a, Chl b and Car contents in group $\mathrm{T}_{4}$ versus CK decreased by 77.17, 81.16, and $83.05 \%$, respectively. One-way ANOVA showed the Chl a, $\mathrm{Chl} \mathrm{b}, \mathrm{Chla}+\mathrm{b}$, and Car contents after $\mathrm{Sb}^{3+}$ treatments were significantly different from the CK $(F=874,166.5,561.2$, 75, respectively; all $P<0.001)$. Multiple comparison results expressed in a-d (Tables 1, 2 and Figures 1-3) showed the data of different letters were significantly different at the 95\% confidence interval (CI). while the data of the same letter were not significantly different at $95 \% \mathrm{CI}$.

The leaf Chl a, Chl b, Chla $+\mathrm{b}$, and Car contents in group $\mathrm{T}^{\prime}{ }_{1}$ all insignificantly increased from the $\mathrm{CK}(P>0.05)$. The contents of these pigments all significantly decreased in groups $\mathrm{T}_{2}^{\prime}, \mathrm{T}^{\prime}{ }_{3}$, and $\mathrm{T}^{\prime}{ }_{4}$ compared with the $\mathrm{CK}(P<0.05)$ and were negatively correlated with the $\mathrm{Sb}^{5+}$ concentration. The $\mathrm{Chl} \mathrm{a} / \mathrm{b}$ minimized to 2.52 in group $\mathrm{T}^{\prime}{ }_{1}$ and maximized to 3.24 in group $\mathrm{T}^{\prime}{ }_{2}$, while the $\mathrm{Chl} / \mathrm{Car}$ ratio rose from 0.23 to 0.30 . One-way ANOVA showed the Chl a, Chl b, Chla + b, and Car contents after $\mathrm{Sb}^{5+}$ treatments were significantly different from the CK $(F=760.9,67.9,688.1$, 26, respectively; all $P<0.001$ ).

\section{Effects of Sb Stress on Seedling Biomass}

The growing parameters of $A$. calamus after different treatments $\left(\mathrm{Sb}^{3+}\right.$ and $\left.\mathrm{Sb}^{5+}\right)$ are listed in Figure 1. The growing conditions of $A$. calamus can be reflected by plant height and plant dry weight. The plant heights, dry aground weights and dry underground weights all decreased significantly with the rise of $\mathrm{Sb}^{3+}$ concentration $\left(\mathrm{T}_{1}, \mathrm{~T}_{2}\right.$, and $\left.\mathrm{T}_{3}\right)$ in a negatively correlated way. $\left(R^{2}=-0.922,-0.935\right.$, and -0.942 , respectively; all $P<0.01)$. The three parameters of group $\mathrm{T}_{4}$ versus CK decreased by 35,36 , and $32.4 \%$, respectively. One-way ANOVA showed the plant heights, dry aground weights and dry underground weights after $\mathrm{Sb}^{3+}$ treatments were significantly different from the $\mathrm{CK}(F=14,7.8$, and 6.8 , respectively; all $P<0.01)$.

As for $\mathrm{Sb}^{5+}$ treatments, the three parameters all maximized in group $\mathrm{T}^{\prime}{ }_{1}$, but were not significantly different from the CK $(P>0.05)$. The three parameters all significantly decreased in groups $\mathrm{T}_{2}^{\prime}, \mathrm{T}^{\prime}{ }_{3}$, and $\mathrm{T}^{\prime}{ }_{4}$ compared the CK $(P<0.05)$. One-way ANOVA showed the plant heights, dry aboveground weights and dry underground weights after $\mathrm{Sb}^{5+}$ treatments were significantly different from the $\mathrm{CK}(F=15.8,7.6$, and 6.2 , respectively; all $P<0.01)$.

\section{Effects of Sb Stress on Aboveground or Underground Sb Accumulation}

The mass fractions of $\mathrm{Sb}$ in underground and aboveground tissues after different treatments $\left(\mathrm{Sb}^{3+}\right.$ and $\left.\mathrm{Sb}^{5+}\right)$ are listed in Table 2. Clearly, after $\mathrm{Sb}^{3+}$ treatments $\left(\mathrm{T}_{1}, \mathrm{~T}_{2}, \mathrm{~T}_{3}\right.$, and $\mathrm{T}_{4}$ ), the underground and aboveground $\mathrm{Sb}$ concentrations fell within $39.72-79.68$ and $9.28-22.15 \mathrm{mg} / \mathrm{kg}$, respectively, showing significant differences among treatments $(P<0.05)$; TF\% varied between 19.44 and $27.8 \%$. One-way ANOVA showed the Sb mass fractions in underground and aboveground tissues after $\mathrm{Sb}^{3+}$ treatments were both significantly different from the CK $(F=2422.9, F=378.4$, both $P<0.001)$.

After $\mathrm{Sb}^{5+}$ treatments $\left(\mathrm{T}_{1}^{\prime}, \mathrm{T}_{2}^{\prime}, \mathrm{T}_{3}^{\prime}\right.$, and $\left.\mathrm{T}_{4}^{\prime}\right)$, the underground and aboveground $\mathrm{Sb}$ concentrations fell within 37.85-78.8 and 8.5-19.59 $\mathrm{mg} / \mathrm{kg}$, respectively, showing significant differences among treatments $(P<0.001)$; TF\% varied between 19.44 and 24.86\%. One-way ANOVA showed the $\mathrm{Sb}$ mass fractions in underground and aboveground tissues after $\mathrm{Sb}^{5+}$ treatments were both significantly different from CK $(F=1939.3, F=243.8$, both $P<0.001)$.

\section{Effects of Sb Stress on Leaf Gas Exchange Parameters of $A$. calamus}

The leaf gas exchange parameters of $A$. calamus after different treatments $\left(\mathrm{Sb}^{3+}\right.$ and $\left.\mathrm{Sb}^{5+}\right)$ are listed in Figure 2. Clearly, the $\mathrm{Pn}, \mathrm{Gs}$, and $\mathrm{E}$ were all negatively correlated with the increasing $\mathrm{Sb}^{3+}$ concentration $\left(R^{2}=-0.8498,-0.8638\right.$, and -0.8453 , respectively; all $P<0.01)$. While $\mathrm{Ci}$ was positively correlated with $\mathrm{Sb}^{3+}$ concentration $\left(R^{2}=0.8824, P<0.01\right)$. The Pn, Gs, and $\mathrm{E}$ of group $\mathrm{T}_{4}$ versus CK decreased by 38.2 , 65.8 and $55.8 \%$, respectively. One-way ANOVA showed the leaf $\mathrm{P}_{n}, \mathrm{G}_{\mathrm{s}}$, and $\mathrm{E}$ after $\mathrm{Sb}^{3+}$ treatments were all significantly different from the CK ( $F=5.6,26.3$, and 30.8, respectively; all $P<0.05)$, but $\mathrm{Ci}$ was not significantly different $(F=2.5, P>0.05)$.

After $\mathrm{Sb}^{5+}$ treatments, the leaf $\mathrm{Pn}, \mathrm{Gs}$, and $\mathrm{E}$ of group $\mathrm{T}^{\prime}{ }_{1}$ all increased insignificantly compared with the CK $(P>0.05)$; 
TABLE 1 | Effects of antimony stress on leaf photosynthetic pigments in A. calamus plants.

\begin{tabular}{|c|c|c|c|c|c|c|c|}
\hline \multicolumn{2}{|c|}{ Sb treatment $\left(\mathrm{mg} \cdot \mathrm{kg}^{-1}\right.$ soil) } & \multirow{2}{*}{ 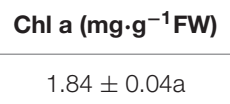 } & \multirow{2}{*}{ 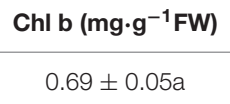 } & \multirow{2}{*}{$\begin{array}{c}\left.\text { Chla+b (mg. } \mathbf{g}^{-\mathbf{1}} \mathbf{F W}\right) \\
2.53 \pm 0.09 a\end{array}$} & \multirow{2}{*}{$\begin{array}{c}\text { Car }\left(\mathbf{m g} \cdot \mathbf{g}^{-\mathbf{1}} \mathbf{F W}\right) \\
0.59 \pm 0.05 \mathrm{a}\end{array}$} & \multirow{2}{*}{$\begin{array}{c}\mathbf{C h l ~ a / b} \\
2.67 \pm 0.14 a\end{array}$} & \multirow{2}{*}{$\frac{\text { Car/Chl }}{0.23 \pm 0.01 a}$} \\
\hline $\mathrm{Sb}^{3+}$ & $\mathrm{CK}(0)$ & & & & & & \\
\hline & $\mathrm{T}_{1}(250)$ & $1.72 \pm 0.02 b$ & $0.54 \pm 0.01 b$ & $2.26 \pm 0.02 b$ & $0.52 \pm 0.04 a$ & $3.19 \pm 0.04 b$ & $0.23 \pm 0.02 a$ \\
\hline & $\mathrm{T}_{2}(500)$ & $1.54 \pm 0.05 c$ & $0.47 \pm 0.04 c$ & $2.01 \pm 0.09 c$ & $0.44 \pm 0.05 b$ & $3.28 \pm 0.14 b$ & $0.22 \pm 0.02 a$ \\
\hline & $\mathrm{T}_{3}(1000)$ & $0.46 \pm 0.04 d$ & $0.14 \pm 0.03 d$ & $0.60 \pm 0.06 d$ & $0.11 \pm 0.01 c$ & $3.29 \pm 0.32 b$ & $0.18 \pm 0.01 b$ \\
\hline & $\mathrm{T}_{4}(2000)$ & $0.43 \pm 0.05 d$ & $0.13 \pm 0.02 d$ & $0.56 \pm 0.06 d$ & $0.10 \pm 0.02 c$ & $3.31 \pm 0.04 b$ & $0.18 \pm 0.02 b$ \\
\hline ANOVA & $\mathrm{F}$ & $874^{* * *}$ & $166.5^{* * *}$ & $561.2^{* * *}$ & $75^{* * *}$ & $7.1^{* * *}$ & $23.5^{* * *}$ \\
\hline \multirow[t]{5}{*}{$\mathrm{Sb}^{5+}$} & $\mathrm{CK}(0)$ & $1.84 \pm 0.04 \mathrm{a}$ & $0.69 \pm 0.05 a$ & $2.53 \pm 0.09 a$ & $0.59 \pm 0.05 a$ & $2.67 \pm 0.14 b$ & $0.23 \pm 0.01 b$ \\
\hline & $\mathrm{T}_{1}(250)$ & $1.89 \pm 0.03 a$ & $0.75 \pm 0.06 a$ & $2.64 \pm 0.09 a$ & $0.62 \pm 0.05 a b$ & $2.52 \pm 0.15 b$ & $0.23 \pm 0.01 b$ \\
\hline & $\mathrm{T}_{2}(500)$ & $1.75 \pm 0.03 b$ & $0.54 \pm 0.05 b$ & $2.29 \pm 0.08 b$ & $0.53 \pm 0.04 b$ & $3.24 \pm 0.25 a$ & $0.23 \pm 0.01 b$ \\
\hline & $\mathrm{T}_{3}(1000)$ & $0.77 \pm 0.04 c$ & $0.27 \pm 0.04 c$ & $1.04 \pm 0.08 c$ & $0.31 \pm 0.02 c$ & $2.85 \pm 0.24 a$ & $0.30 \pm 0.01 a$ \\
\hline & $\mathrm{T}_{4}(2000)$ & $0.72 \pm 0.04 c$ & $0.25 \pm 0.05 c$ & $0.97 \pm 0.09 c$ & $0.27 \pm 0.02 c$ & $2.88 \pm 0.35 a$ & $0.28 \pm 0.02 a$ \\
\hline ANOVA & $\mathrm{F}$ & $760.9^{* * *}$ & $67.9^{* * *}$ & $288.1^{* * *}$ & $26^{* * *}$ & $4^{* * *}$ & $152.4^{* * *}$ \\
\hline
\end{tabular}

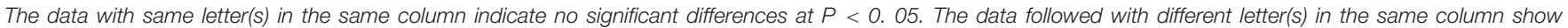
significant differences at $P<0.05 .{ }^{* * *} P<0.001$. The same in the following tables and figures.

TABLE 2 | Effects of antimony stress on $\mathrm{Sb}$ content of $A$. calamus.

\begin{tabular}{|c|c|c|c|c|}
\hline \multicolumn{2}{|c|}{ Sb treatment $\left(\mathbf{m g} \cdot \mathbf{k g}^{-1}\right.$ soil) } & \multicolumn{2}{|c|}{ Net Sb content in plant tissues $\left(\mathrm{mg} \cdot \mathrm{kg}^{-1} \mathrm{DW}\right.$ biomass) } & \multirow{2}{*}{$\begin{array}{l}\text { Translocation factor from } \\
\text { underground to } \\
\text { aboveground parts (TF\%) }\end{array}$} \\
\hline & & Underground part & Aboveground part & \\
\hline \multirow[t]{5}{*}{$\mathrm{Sb}^{3+}$} & $\mathrm{CK}(0)$ & $0.36 \pm 0.02 d$ & $0.07 \pm 0.01 c$ & 19.44 \\
\hline & $\mathrm{T}_{1}(250)$ & $39.72 \pm 1.0 c$ & $9.28 \pm 0.51 b$ & 23.36 \\
\hline & $\mathrm{T}_{2}(500)$ & $42.59 \pm 1.17 \mathrm{c}$ & $10.65 \pm 0.53 b$ & 25.01 \\
\hline & $\mathrm{T}_{3}(1000)$ & $73.27 \pm 1.32 b$ & $19.34 \pm 0.89 a$ & 26.40 \\
\hline & $\mathrm{T}_{4}(2000)$ & $79.68 \pm 1.45 a$ & $22.15 \pm 0.88 a$ & 27.80 \\
\hline ANOVA & $\mathrm{F}$ & $2422.9^{* * *}$ & $378.4^{* * *}$ & \\
\hline \multirow[t]{5}{*}{$\mathrm{Sb}^{5+}$} & $\mathrm{CK}(0)$ & $0.36 \pm 0.02 d$ & $0.07 \pm 0.01 c$ & 19.44 \\
\hline & $\mathrm{T}^{\prime}{ }_{1}(250)$ & $37.85 \pm 1.38 c$ & $8.50 \pm 3.70 b$ & 22.46 \\
\hline & $\mathrm{T}_{2}^{\prime}(500)$ & $41.07 \pm 1.17 \mathrm{c}$ & $9.63 \pm 0.43 b$ & 23.44 \\
\hline & $\mathrm{T}_{3}^{\prime}(1000)$ & $71.54 \pm 1.30 b$ & $17.25 \pm 0.79 a$ & 24.11 \\
\hline & $\mathrm{T}_{4}^{\prime}(2000)$ & $78.80 \pm 1.61 a$ & $19.59 \pm 0.73 a$ & 24.86 \\
\hline ANOVA & $F$ & $1939.3^{* * *}$ & $243.8^{* * *}$ & \\
\hline
\end{tabular}

the three parameters in groups $\mathrm{T}^{\prime}{ }_{2}, \mathrm{~T}^{\prime}{ }_{3}$, and $\mathrm{T}^{\prime}{ }_{4}$ all significantly decreased (all $P<0.05$ ). One-way ANOVA showed the leaf Pn, Gs, E, and $\mathrm{Ci}$ after $\mathrm{Sb}^{5+}$ treatments were all significantly different from the $\mathrm{CK}(F=4.7,33.1,28.3, F=3.6$, respectively; all $P<0.05)$.

\section{Effects of Sb Stress on Leaf Chlorophyll Fluorescence Parameters of $A$. calamus}

The leaf chlorophyll fluorescence parameters of $A$. calamus after different treatments $\left(\mathrm{Sb}^{3+}\right.$ and $\left.\mathrm{Sb}^{5+}\right)$ are listed in Figure 3. The $\mathrm{F}_{\mathrm{v}} / \mathrm{F}_{\mathrm{m}}$ and $\Phi_{\mathrm{PSII}}$ both decreased significantly with the rising $\mathrm{Sb}^{3+}$ concentration in a negatively correlated way $\left(R^{2}=-0.9306\right.$, -0.9619 ; both $P<0.01)$. The $\mathrm{F}_{\mathrm{v}} / \mathrm{F}_{\mathrm{m}}$ and $\Phi_{\mathrm{PSII}}$ of group $\mathrm{T}_{4}$ versus the CK decreased significantly by 31.6 and $34.5 \%$, respectively (both $P<0.05$ ). One-way ANOVA showed the $\mathrm{F}_{\mathrm{v}} / \mathrm{F}_{\mathrm{m}}$ and $\Phi_{\mathrm{PSII}}$ after $\mathrm{Sb}^{3+}$ treatments, were significantly different from the $\mathrm{CK}$ $(F=102, F=82$, both $P<0.001)$.
The $\mathrm{F}_{\mathrm{V}} / \mathrm{F}_{\mathrm{m}}$ and $\Phi_{\mathrm{PS} I I}$ of group $\mathrm{T}_{2}^{\prime}, \mathrm{T}^{\prime}{ }_{3}$, and $\mathrm{T}_{4}^{\prime}$ versus the CK all decreased significantly (all $P<0.05$ ), but increased insignificantly in group $\mathrm{T}^{\prime}{ }_{1}$ (both $P>0.05$ ). One-way ANOVA showed the $\mathrm{F}_{\mathrm{V}} / \mathrm{F}_{\mathrm{m}}$ and $\Phi_{\mathrm{PSII}}$ after $\mathrm{Sb}^{5+}$ treatments were significantly different from the CK $(F=96, F=46$, both $P<0.001)$.

\section{DISCUSSION AND CONCLUSIONS}

Chlorophylls are an important type of pigments needed by plants for photosynthesis and participate in optical energy absorption, transfer and conversion during photosynthesis. Chlorophylls are pivotal in photosynthesis and their content variations reflect the degree of photosynthesis (Bot et al., 1990; Zhang et al., 2011). However, heavy metals (e.g., $\mathrm{Ni}, \mathrm{Cu}$ ) could induce toxic effects on chlorophylls, such as synthesis inhibition and 

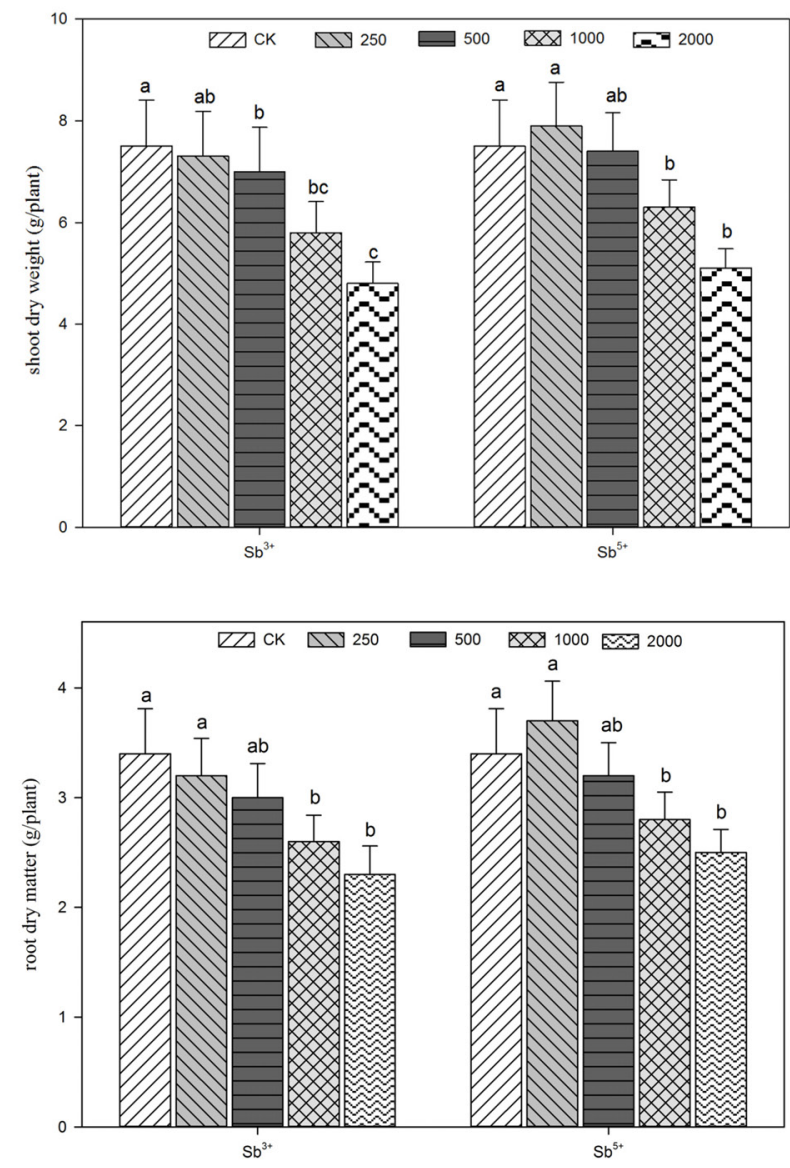

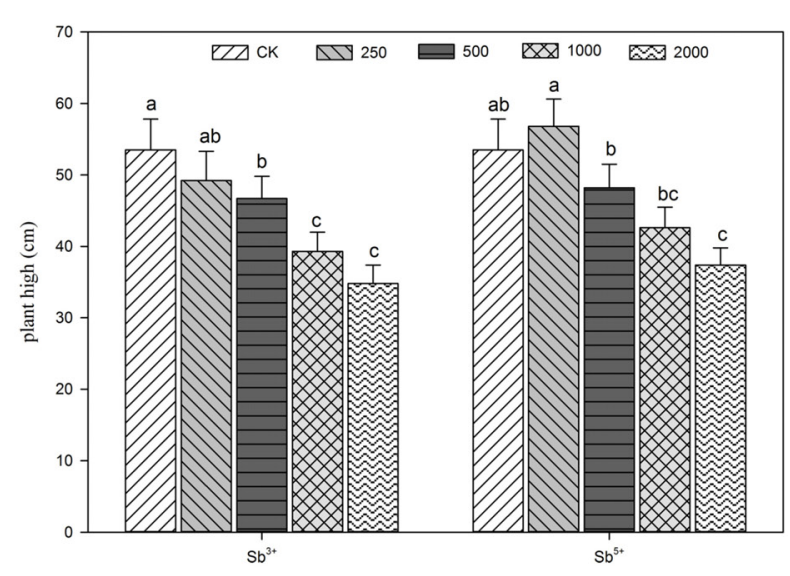

FIGURE 1 | Influences of biomass accumulation of $A$. calamus by antimony stress.

structural destruction (Sreekanth et al., 2013; Llagostera et al., 2016).

In this study, the pigment contents all decreased under highconcentration Sb stress $(500-2000 \mathrm{mg} / \mathrm{kg})$. The possible reason is that though $\mathrm{Sb}$ is not necessary to the growth of A. calamus, when the environmental $\mathrm{Sb}$ concentration rises, more $\mathrm{Sb}$ would enter plant cells to bind with the sulfhydryl group of chloroplast proteins, destroying the structures and functions of chloroplasts and disturbing the balanced chlorophyll enzymatic activity ratios. As a result, the accelerated chlorophyll decomposition and broken physiological balance would decrease chlorophyll contents, photosynthesis, growth, and biomass in vivo. Moreover, under $\mathrm{Sb}$ stress, Sb accumulates largely in roots (Table 2), which may interfere with the cation absorption and chlorophyll synthesis of plants, and block the transportation of some nutrient elements into leaves.

The Chl a/b ratios in groups $T_{1}, T_{2}, T_{3}$, and $T_{4}$ basically rose with the increasing $\mathrm{Sb}^{3+}$ concentration, but changed in different ways from $\mathrm{Chl}$ a or $\mathrm{Chl} \mathrm{b}$ concentrations. The $\mathrm{Chl}$ $\mathrm{a} / \mathrm{b}$ ratio reflects the ratio between the appressed and nonappressed membrane regions, and is inversely proportional to the degree of thylakoid oppression (Anderson and Aro, 1994), a way where the plants adaptively use optical energy to the largest extent. Firstly, thylakoid oppression makes light-harvesting chlorophyll-protein complexes (LHCII) more tightly connected and improves the light-harvesting ability and energy transfer efficiency (Dutta, 1986). Secondly, thylakoid oppression enhances the photoinduced electron/proton transfer ability of the PSII and cytochrome bf complex, and thereby most largely accelerates the linear electron transfer (Chow, 1999). The rise of Chl a/b ratio induced by $\mathrm{Sb}$ stress may also indicate the partial thylakoid unoppression and the occurrence of photoinhibition in leaves. The reduction of thylakoid oppression contributes to dissipation of excessive excitation energy and is an active manifestation of A. calamus in adaptation to environmental stress. $\mathrm{Chl} b$ is more prone to Sb-induced than $\mathrm{Chl} \mathrm{a}$, and the reduction of $\mathrm{Chl} \mathrm{b}$ and $\mathrm{Chl}$ a contents reflects the leaf senescence. The reduction of relative $\mathrm{Chl} b$ content would reduce optical energy capture, active $\mathrm{O}$ generation, and protein degradation, which improve the Sb-tolerance of $A$. calamus.

The Chl a/b ratios in groups $\mathrm{T}_{1}^{\prime}, \mathrm{T}_{2}^{\prime}, \mathrm{T}^{\prime}{ }_{3}$, and $\mathrm{T}_{4}^{\prime}$ changed in very complicatedly ways, probably because the $\mathrm{Sb}$ absorption led to a metabolic disorder in A. calamus. The Car/Chl ratio was basically stable with the presence of $0-500 \mathrm{mg} / \mathrm{kg} \mathrm{Sb}$, but significantly decreased in groups $\mathrm{T}_{3}$ and $\mathrm{T}_{4}$ compared with the CK $(P<0.01)$, and significantly rose in groups 

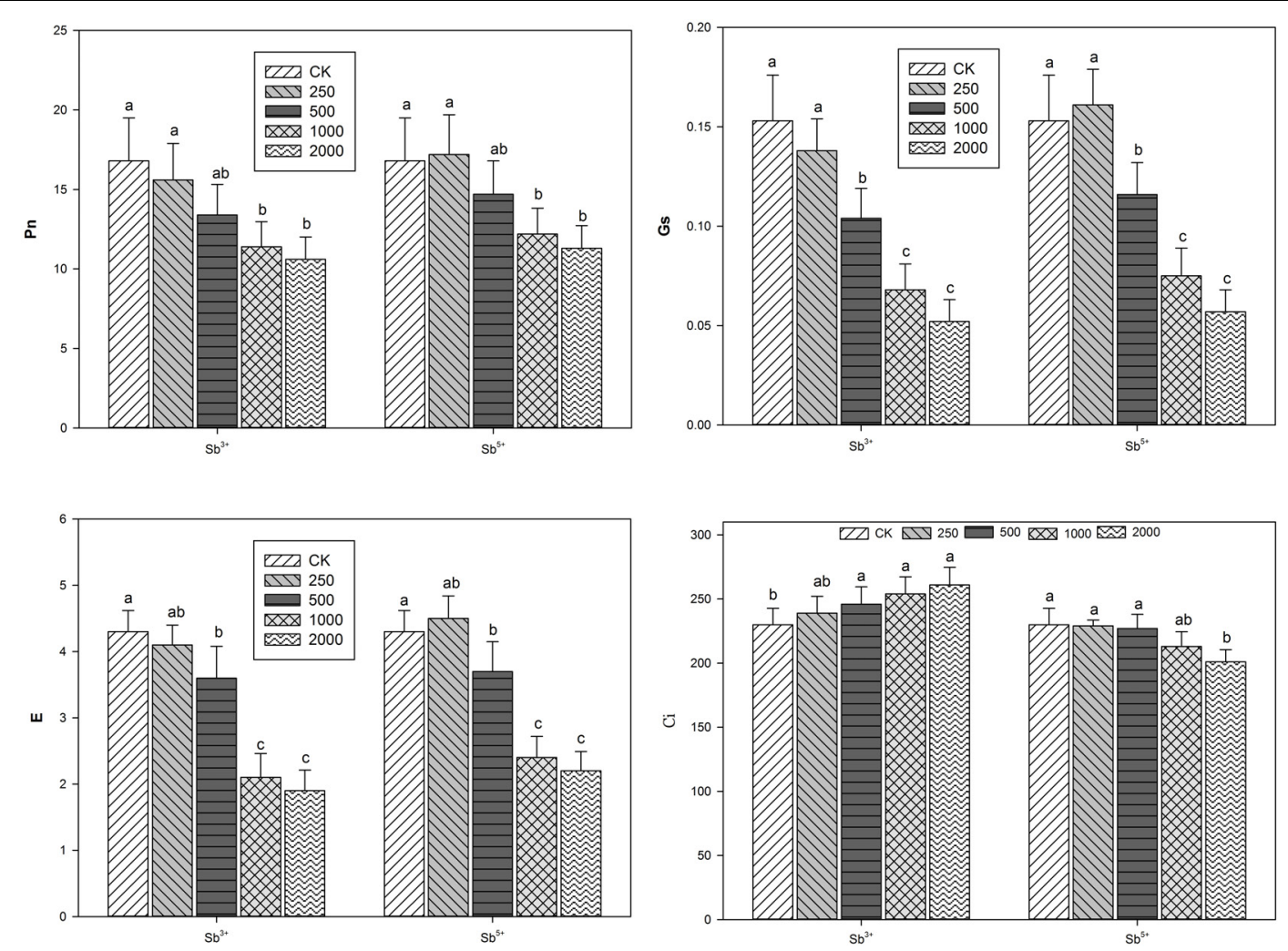

FIGURE 2 | Effects Sb concentrations on gas exchange parameters of $A$. calamus.
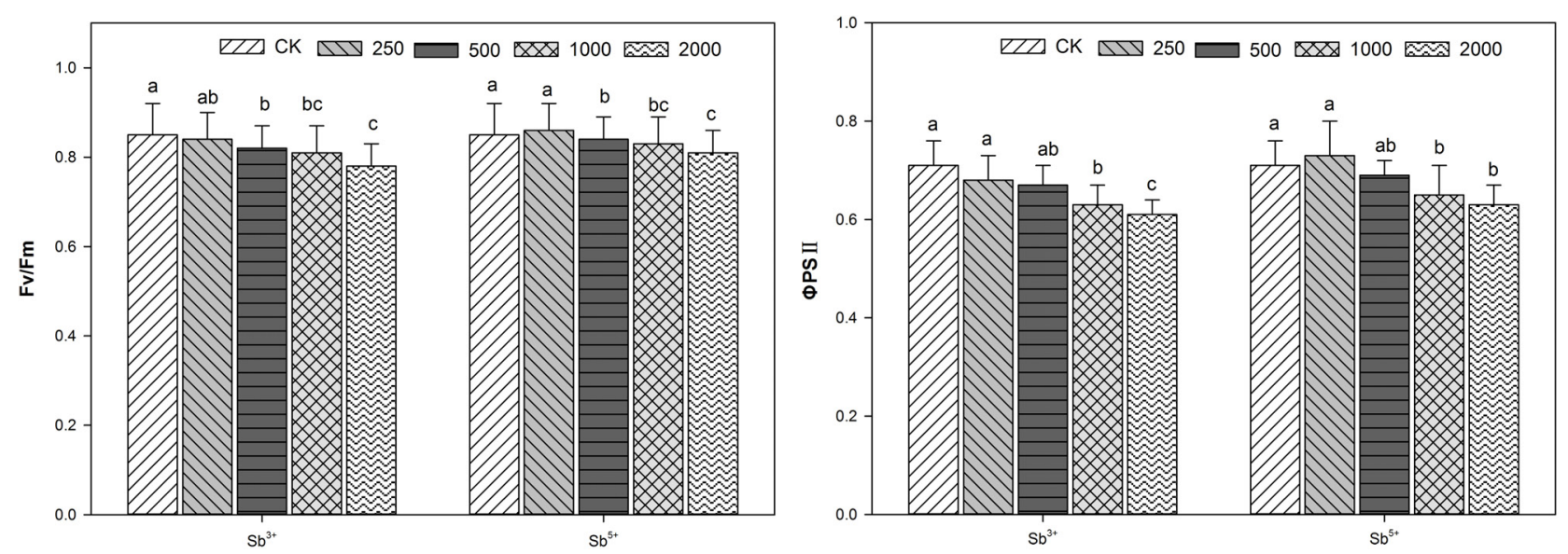

FIGURE 3 | Effects of Sb concentrations on the chlorophyll fluorescence parameters of $A$. calamus.

$\mathrm{T}^{\prime}{ }_{3}$ and $\mathrm{T}^{\prime}{ }_{4}(P<0.01)$, indicating the effects of $\mathrm{Sb}$ on carotenoids of A. calamus are complicated when different forms are considered. Carotenoids can absorb visible light and transfer the absorbed optical energy to chlorophyll a, and can antioxidate and dissipate excessive optical energy. The $\mathrm{Sb}$ stress causes carotenoid degradation, and thereby structural change of thylakoid membranes, reduction of electron transfer and PSII activity. However, Sb stress destroys the ability of carotenoids to clear away oxygen free radicals in vivo in A. calamus, destabilizing thylakoid membranes and harming the plants.

Plant height reflects the effects of $S b$ stress on the growth and development of A. calamus. The toxicity of Sb would make leaves thinner, smaller, less developed and the plants shorter. Beyond a certain concentration, $\mathrm{Sb}$ stress would inhibit the growth of A. calamus and reduce physiological activity. A. calamus can 
adopt antioxidation enzyme systems (e.g., superoxide dismutase SOD, peroxidase POD) in vivo to efficiently relieve the harms of low Sb stress, but the Sb concentration exceeding a certain level could weaken the stress-resistant ability and inhibits plant growth, which is manifested as a reduction of plant height, dry weight and biomass.

The translocation factor (TF\%) is the concentration ratio of an element in the aboveground part to the underground part of a plant. TF\% reflects the ability of a heavy metal to transfer from the underground part to the aboveground part (e.g., leaves, stem) (Islam et al., 2013). In A. calamus, the antimony concentration is about four times higher in underground part than in aboveground part, and TF\% is from $19.44 \%$ to $27.8 \%$. As reported, the $\mathrm{Sb}$ accumulation in maize was promoted by the rise of soil $\mathrm{Sb}$ concentration, and $\mathrm{Sb}$ easily transferred from roots to shoots, with the largest TF\% of 2.05 (Dwivedi et al., 2015). The high soil Sb concentrations significantly reduced the growth and biomass of maize, and inhibited the activities of POD and SOD (Dwivedi et al., 2015). Thus, the TF\% of Sb may be related to the plant species and Sb concentration (Pan et al., 2011). The root $\mathrm{Sb}$ concentration of the arsenic hyperaccumulator Pteris vittata reached $12000 \mathrm{mg} / \mathrm{kg}$ and accounted for $99 \%$ of hosted Sb in the plants (Tisarum et al., 2014). The enrichment ability of sunflower (Helianthus annuus L.) under Sb stress was larger in roots than in leaves, but Sb stress inhibited plant growth; the $\mathrm{Sb}$ accumulation in the aboveground part significantly altered the physical conditions of sunflower, reduced intercellular gaps and made leaf tissues closer (Vaculík et al., 2015; Ortega et al., 2017). According to the report, root is the main organ for taking up metal nanoparticles from water are badly influenced in comparison with shoot in some plants (Tripathi et al., 2016; Anshu et al., 2017).

Acorus calamus is a Sb non-hyperaccumulator, and the rootabsorbed Sb is mostly hosted in roots, which avoids the transfer to the aboveground part and the occurrence of harms. This detoxification mechanism is very significant in eliminating the biological toxicity of $\mathrm{Sb}$ from the aboveground part. A larger TF\% indicates the aboveground part is more able to accumulate a heavy metal and transfer the majority to the aboveground part, where the heavy metal can be removed during harvest. With the increase of $\mathrm{Sb}$ concentration in the growing medium, the TF\% rises in significantly $(P>0.05$; Table 2$)$, indicating the $\mathrm{Sb}$ absorbed by $A$. calamus is mostly enriched in the underground part, which is favorable for plant growth and enhances the stress resistance. In comparison, the change of the total concentration of antimony in the growth substrate is closely accords with that of roots $\mathrm{Sb}$ concentration of A. calamus $\left(R^{2}=0.82\right)$. Phytoremediation technology in which plants take up the contaminants from the soil/water and keep them in the root system is categorized as phytostabilization. According to the remediation mechanisms, phytoremediation falls into five general categories:phytofiltration, phytoextraction, phytodegradation, phytostabilization, and phytovolatilization (Sytar et al., 2016).

Background value of antimony in terrestrial vascular plants was less than $0.05 \mathrm{mg} / \mathrm{kg}$ dry weight (Baroni et al., 2000), and antimony accumulated to $5-10 \mathrm{mg} / \mathrm{kg}$ in plant tissue would be toxic to plant (Kabata-Pendias and Pendias, 2010). But in the present study, $\mathrm{Sb}$ concentrations in the highest $79.68 \mathrm{mg} / \mathrm{kg}$ dry weight didn't cause the death of A. calamus, so A. calamus had some resistance to antimony.

$\mathrm{Sb}$ level in the underground of Plantago lanceolata were $1150 \mathrm{mg} / \mathrm{kg}$ dry weight, yet Plantago lanceolata are not used to deal with antimony polluted water (Baroni et al., 2000). Sb levels in shoots of Typha latifolia, Scirpus sylvaticus, and Phragmites australis were 15,19 , and $15 \mathrm{mg} / \mathrm{kg}$ dry weight, respectively; the accumulation ability of $S b$ in A. calamus (shoots, $22.15 \mathrm{mg} / \mathrm{kg}$ dry weight) is better than three aquatic plants.

Phytoremediation is a new cheap and eco-friendly technique that depends plants to clean the environmental pollution by heavy metals (Sytar et al., 2016). In the present study, the aquatic plant A. calamus was tested for its ability to accumulate $\mathrm{Sb}$ from contaminated water in laboratory experiments. The results showed that A. calamus serves as a good candidate for phytoremediation of water contaminated with Sb.

Photosynthesis, an important evaluation criterion of plant productivity, is a physiological process very sensitive to heavy metal stress and directly provides energy for plant growth and development. The photosynthesis ability of A. calamus as a wetland plant is related with its ability to absorb pollutants from water. Generally, stomatal factors mainly include the number, size and opening degree of stomas, while non-stomatal factors include enzymatic activity and photosynthesis components. Under environmental stresses, both stomatal limitation and nonstomatal limitation could lead to the reduction of Pn (Lal et al., 1996; Wu et al., 2014) and can be basically discriminated by $\mathrm{Ci}$. When Pn and Ci both decrease, the decrease of photosynthesis ability is induced by stomatal limitation; when Pn declines but $\mathrm{Ci}$ increases, the cause is non-stomatal limitation (Farquhar and Sharkey, 1982).

In addition to the stoma closure, the reduction of Pn is also related to the decrease of mesophyll cell photosynthetic activity. In our study, Pn declined but Ci rose in groups $T_{1}, T_{2}, T_{3}$, and $\mathrm{T}_{4}$, indicating the reduction of Pn was mainly caused by nonstomatal factors and that the mesophyll cells of A. calamus were injured and the photosynthesis activity was weakened, leading to the reduction of $\mathrm{CO}_{2}$ fixation ability and the accumulation of intercellular $\mathrm{CO}_{2}$. The photosynthesis parameters all maximized with the presence of $250 \mathrm{mg} / \mathrm{kg} \mathrm{Sb}{ }^{5+}$, but the inhibitory effects of high concentrations $(500-2000 \mathrm{mg} / \mathrm{kg})$ on photosynthesis were gradually enhanced. Pn and Ci decline simultaneously, indicating the partial stoma closure is the main cause of photosynthetic rate reduction.

Chlorophyll fluorescence is an ideal probe to study the relationship between photosynthesis and environmental stress and provides rich information for researth on PSII and electron transfer. The chlorophyll fluorescence properties reflect the relationship between photosynthesis physiology and environmental stress. $\mathrm{F}_{\mathrm{v}} / \mathrm{F}_{\mathrm{m}}$ is the major index of PSII photochemical efficiency and reflects the initial optical energy conversion efficiency. $\mathrm{F}_{\mathrm{v}} / \mathrm{F}_{\mathrm{m}}$ indicates the optical energy using ability of PSII and is closely related to the photosynthesis inhibition degree. The presence of stress would reduce $\mathrm{F}_{\mathrm{v}} / \mathrm{F}_{\mathrm{m}}$ 
and destroy the PSII reaction centers. In our study, with the increase of $\mathrm{Sb}$ concentration, the $\mathrm{F}_{\mathrm{V}} / \mathrm{F}_{\mathrm{m}}$ declined in groups $\mathrm{T}_{1}, \mathrm{~T}_{2}, \mathrm{~T}_{3}$, and $\mathrm{T}_{4}$, indicating the PSII reaction centers were destroyed. $\Phi_{\text {PSII }}$ indicates the real photochemical efficiency upon the partial closure of reaction centers when the PSII reaction centers are stressed environmentally. PSII was confirmed as an important site of photoinhibition, but its light use efficiency can be reduced by drought/flooding, heavy metals, saline or other stress factors, and there by the plants were injured by photoinhibition. As reported, the chlorophyll fluorescence parameters of Ramie (Boehmeria nivea L.) including $\mathrm{F}_{\mathrm{V}} / \mathrm{F}_{\mathrm{m}}$ and $\Phi_{\mathrm{PSII}}$ were not significantly changed under $\mathrm{Sb}$ stress (20-200 mg. $\mathrm{L}^{-1}$ ) (Chai et al., 2016), but were significantly reduced under salty or drought stress (Huang et al., 2013). The maximum photochemical quantum yield $\left(\mathrm{F}_{\mathrm{v}} / \mathrm{F}_{\mathrm{m}}\right)$ of maize under Sb stress (50-1000 mg. $\mathrm{kg}^{-1}$ soil) declined (Zhang et al., 2017). A. utriculata is a nickel hyperaccumulator, and its $\mathrm{F}_{\mathrm{v}} / \mathrm{F}_{\mathrm{m}}$ was basically unchanged after high concentration treatment and its photosynthetic performance was still high (Roccotiello et al., 2016). Excessive cadmium inhibits the effects of photosynthesis by means of disrupting the PSII functions, however, different from $\mathrm{Cd}$, lead $(\mathrm{Pb})$ stress inhibits the effects of photosynthesis by disrupting chloroplast ultrastructure and thylakoid membrane lipid composition (Kalaji et al., 2016).

In our study, $\mathrm{F}_{\mathrm{V}} / \mathrm{F}_{\mathrm{m}}$ and $\Phi_{\mathrm{PSII}}$ both significantly decreased after treatments $\mathrm{T}_{2}^{\prime}, \mathrm{T}^{\prime}{ }_{3}$, and $\mathrm{T}^{\prime}{ }_{4}$ compared with the control, but the declining amplitudes were smaller than in treatments $T_{2}, T_{3}$, and $\mathrm{T}_{4}$, indicating $\mathrm{Sb}^{5+}$ and $\mathrm{Sb}^{3+}$, after reaching certain levels, both could damage the PSII reaction centers.

\section{REFERENCES}

Anderson, J. M., and Aro, E. M. (1994). Grana stacking and protection of photosystem II in thylakoid membranes of higher plant leaves under sustained high irradiance: an hypothesis. Photosynth. Res. 41, 315-326. doi: 10.1007/ BF00019409

Anshu, R., Marek, Z., Oksana, S., Kalaji, H. M., He, X., Sonia, M., et al. (2017). Impact of metal and metal oxide nanoparticles on plant: a critical review. Front. Chem. 5:78. doi: 10.3389/fchem.2017.00078

Baroni, F., Boscagli, A., Protano, G., and Riccobono, F. (2000). Antimony accumulation in achillea ageratum, plantago lanceolata and silene vulgaris growing in an old sb-mining area. Environ. Pollut. 109, 347-352. doi: 10.1016/ S0269-7491(99)00240-7

Bot, J. L., Goss, M. J., Carvalho, M. J. G. P. R., Beusichem, M. L. V., and Kirkby, E. A. (1990). The significance of the magnesium to manganese ratio in plant tissues for growth and alleviation of manganese toxicity in tomato (Lycopersicon esculentum) and wheat (Triticum aestivum) plants. Plant Soil 124, 205-210. doi: 10.1007/BF00009261

Cai, F., Ren, J. H., Tao, S., and Wang, X. L. (2016). Uptake, translocation and transformation of antimony in rice (Oryza sativa L.) seedlings. Environ. Pollut. 209, 169-176. doi: 10.1016/j.envpol.2015.11.033

Chai, L. Y., Mubarak, H., Yang, Z. H., Yong, W., Tang, C. J., and Mirza, N. (2016). Growth, photosynthesis, and defense mechanism of antimony (Sb)contaminated Boehmeria nivea L. Environ. Sci. Pollut. Res. Int. 23, 7470-7481. doi: 10.1007/s11356-015-5987-0

Chow, W. S. (1999). Grana formation: entropy-assisted local order in chloroplasts? Funct. Plant Biol. 26, 641-647. doi: 10.1071/PP99024

Cidu, R., Biddau, R., Dore, E., Vacca, A., and Marini, L. (2014). Antimony in the soil-water-plant system at the su suergiu abandoned mine (sardinia, italy): strategies to mitigate contamination. Sci. Total Environ. 497-498, 319-331. doi: 10.1016/j.scitotenv.2014.07.117
In conclusion, different from the $\mathrm{Sb}^{3+}$ treatment, the $\mathrm{Sb}^{5+}$ treatment showed a Hormesi effect, as low-concentration treatment promoted A. calamus growth, but high-concentration treatment inhibited its growth. The two forms of $\mathrm{Sb}$ both caused unfavorable effects on the growth of A. calamus, but the seedlings did not die and were modestly adaptive and $\mathrm{Sb}$-accumulative. In the current research, the aquatic plant A. calamus, which is easily maintained and cultivated, can serve as a good candidate for phytoremediation of Sb-polluted areas.

\section{AUTHOR CONTRIBUTIONS}

$\mathrm{XZ}$ conducted the experimental design and statistic analysis. CS and PZ analyzed the data. FL wrote the paper with assistance from XZ. All authors commented on an earlier draft of manuscript.

\section{FUNDING}

This work was funded by the National Science Foundation of China (No. 41371444), the Innovation Team of Scientific Research Platform of Anhui Province, China (No. KJ2015TD001), Provincial Natural Science Foundation of Anhui (No.1508085QD73), the Natural Science Foundation from Educational Commission of Anhui Province (Nos. KJ2015A319 and KJ2016B013), and the University Students' Innovation and Pioneering Program (No. 201610373016).

Corrales, I., Barceló, J., Bech, J., and Poschenrieder, C. (2014). Antimony accumulation and toxicity tolerance mechanisms in Trifolium, species. J. Geochem. Explor. 147, 167-172. doi: 10.1016/j.gexplo.2014. 07.002

Dutta, M. J. (1986). Molecular organisation of the photosynthetic membranes of higher plants. Biochim. Biophys. Acta 864, 33-94. doi: 10.1016/0304-4157(86) 90015-8

Dwivedi, A. K., Srivastava, S., Dwivedi, S., and Tripathi, V. (2015). Natural bioremediation of arsenic contamination: a short review. Hydrol. Curr. Res. 6, 1-4. doi: 10.4172/2157-7587.1000186

Farquhar, G. D., and Sharkey, T. D. (1982). Stomatal conductance and photosynthesis. Annu. Rev. Plant Physiol. 33, 317-345. doi: 10.1146/annurev. pp.33.060182.001533

Feng, R. W., Wei, C. Y., Tu, S. X., Ding, Y. Z., Wang, R. G., and Guo, J. K. (2013). The uptake and detoxification of antimony by plants: a review. Environ. Exp. Bot. 96, 28-34. doi: 10.1016/j.envexpbot.2013.08.006

Filella, M., Belzile, N., and Chen, Y. W. (2002). Antimony in the environment: a review focused on natural waters I. Occurrence. Earth Sci. Rev. 57, 125-176. doi: 10.1016/S0012-8252(01)00070-8

Filella, M., Williams, P. A., and Belzile, N. (2009). Antimony in the environment: knows and unknowns. Environ. Chem. 6, 95-105. doi: 10.1071/EN09007

Fu, Z. Y., Wu, F. C., Mo, C. L., Liu, B. J., Zhu, J., Deng, Q. J., et al. (2011). Bioaccumulation of antimony, arsenic, and mercury in the vicinities of a large antimony mine, china. Microchem. J. 97, 12-19. doi: 10.1016/j.microc.2010. 06.004

He, M. C., Wang, X. Q., Wu, F. C., and Fu, Z. Y. (2012). Antimony pollution in china. Sci. Total. Environ. 421-422, 41-50. doi: 10.1016/j.scitotenv.2011.06.009

Huang, C. J., Zhao, S. Y., Wang, L. C., Anjum, S. A., Man, C., Zhou, H. F., et al. (2013). Alteration in chlorophyll fluorescence, lipid peroxidation and antioxidant enzymes activities in hybrid ramie (Boehmeria nivea L.) under drought stress. Aust. J. Crop Sci. 7, 594-599. 
Huang, Y. C., Chen, Z., and Liu, W. J. (2012). Influence of iron plaque and cultivars on antimony uptake by and translocation in rice (Oryza sativa, L.) seedlings exposed to $\mathrm{Sb}(\mathrm{III})$ or $\mathrm{Sb}(\mathrm{V})$. Plant Soil 352, 41-49. doi: 10.1007/s11104-0110973-x

Islam, M. S., Ueno, Y., Sikder, M. T., and Kurasaki, M. (2013). Phytofiltration of arsenic and cadmium from the water environment using Micranthemum umbrosum (J.F. Gmel) S.F Blake as a hyperaccumulator. Int. J. Phytoremediation 15, 1010-1021. doi: 10.1080/15226514.2012.751356

Ji, Y., Sarret, G., Schulin, R., and Tandy, S. (2017). Fate and chemical speciation of antimony $(\mathrm{Sb})$ during uptake, translocation and storage by rye grass using XANES spectroscopy. Environ. Pollut. 231, 1322-1329. doi: 10.1016/j.envpol. 2017.08.105

Kabata-Pendias, A., and Pendias, H. (2010). Trace Elements in Soils and Plants, 4th Edn. Boca Raton, FL: CRC Press. doi: 10.1201/b10158

Kalaji, H. M., Jajoo, A., Oukarroum, A., Brestic, M., Zivcak, M., Samborska, I. A., et al. (2016). Chlorophyll a fluorescence as a tool to monitor physiological status of plants under abiotic stress conditions. Acta Physiol. Plant. 38, 1-12. doi: 10.1007/s11738-016-2113-y

Kamiya, T., and Fujiwara, T. (2009). Arabidopsis NIP1;1 transports antimonite and determines antimonite sensitivity. Plant Cell Physiol. 50, 1977-1981. doi: $10.1093 /$ pcp/pcp130

Karacan, M. S., Rodionova, M. V., Tunç, T., Venedik, K. B., Mamaş, S., Shitov, A. V., et al. (2016). Characterization of nineteen antimony(III) complexes as potent inhibitors of photosystem II, carbonic anhydrase, and glutathione reductase. Photosynth. Res. 130, 1-16. doi: 10.1007/s11120-0160236-z

Lal, A., Ku, M. S. B., and Edwards, G. E. (1996). Analysis of inhibition of photosynthesis due to water stress in the $\mathrm{C} 3$ species Hordeum vulgare and Vicia faba: electron transport, $\mathrm{CO} 2$ fixation and carboxylation capacity. Photosynth. Res. 49, 57-69. doi: 10.1007/BF00029428

Li, Y. K., Liu, F., Zhou, X. J., Wang, X., Liu, Q. C., Zhu, P. F., et al. (2017). Distribution and ecological risk assessment of heavy metals in sediments in chinese collapsed lakes. Pol. J. Environ. Stud. 26, 181-188. doi: 10.15244/pjoes/ 64379

Liu, F., Deng, D. G., Yang, L., Shao, Y. Q., Zhu, P. F., and Ji, L. (2013). Risk evaluation of heavy metals in the surface sediments of lake chaohu in china. Fresen. Environ. Bull. 22, 1807-1813. doi: 10.1007/s11356-015-5246-4

Liu, F., Le, X. C., Mcknight-Whitford, A., Xia, Y. L., Wu, F. C., Elswick, E., et al. (2010). Antimony speciation and contamination of waters in the Xikuangshan antimony mining and smelting area, china. Environ. Geoehem. Health 32, 401-413. doi: 10.1007/s10653-010-9284-z

Llagostera, I., Cervantes, D., Sanmartí, N., Romero, J., and Pérez, M. (2016). Effects of copper exposure on photosynthesis and growth of the seagrass cymodocea nodosa: an experimental assessment. Bull Environ. Contam. Toxicol. 97, 374-379. doi: 10.1007/s00128-016-1863-y

Ortega, A., Garrido, I., Casimiro, I., and Espinosa, F. (2017). Effects of antimony on redox activities and antioxidant defence systems in sunflower (Helianthus annuus L.) plants. PLoS One 12:e183991. doi: 10.1371/journal.pone.0183991

Pan, X. L., Zhang, D. Y., Chen, X., Bao, A. M., and Li, L. H. (2011). Antimony accumulation, growth performance, antioxidant defense system and photosynthesis of zea mays, in response to antimony pollution in soil. Water Air Soil Pollut. 215, 517-523. doi: 10.1007/s11270-010-0496-8

Pierart, A., Dumat, C., Maes, A. Q., and Sejalon-Delmas, N. (2017). Influence of arbuscular mycorrhizal fungi on antimony phyto-uptake and compartmentation in vegetables cultivated in urban gardens. Chemosphere 191, 272-279. doi: 10.1016/j.chemosphere.2017.10.058
Roccotiello, E., Serrano, H. C., Mariotti, M. G., and Branquinho, C. (2016). The impact of $\mathrm{Ni}$ on the physiology of a mediterranean Ni-hyperaccumulating plant. Environ. Sci. Pollut. Res. 23, 12414-12422. doi: 10.1007/s11356-016-6461-3

Shtangeeva, I., Steinnes, E., and Lierhagen, S. (2012). Uptake of different forms of antimony by wheat and rye seedlings. Environ. Sci. Pollut. Res. 19, 502-509. doi: 10.1007/s11356-011-0589-y

Sreekanth, T. V. M., Nagajyothi, P. C., Lee, K. D., and Prasad, T. N. V. K. V. (2013). Occurrence, physiological responses and toxicity of nickel in plants. Int. J. Environ. Sci. Tecnol. 10, 1129-1140. doi: 10.1007/s13762-013-0245-9

Sytar, O., Brestic, M., Taran, N., and Zivcak, M. (2016). "Plants used for biomonitoring and phytoremediation of trace elements in soil and water," in Plant Metal Interaction: Emerging Remediation Techniques, ed. P. Ahmad (Amsterdam: Elsevier Press), 361-384.

Tisarum, R., Lessl, J., Dong, X. L., Oliveira, L. D. M., Rathinasabapathi, B., and Ma, L. Q. (2014). Antimony uptake, efflux and speciation in arsenic hyperaccumulator Pteris vittata. Environ. Pollut. 186, 110-114. doi: 10.1016/j. envpol.2013.11.033

Tripathi, D. K., Singh, S., Singh, S., Srivastava, P. K., Singh, V. P., Singh, S., et al. (2016). Nitric oxide alleviates silver nanoparticles (AgNps)-induced phytotoxicity in Pisum sativum seedlings. Plant Physiol. Biochem. 110, 167-177. doi: 10.1016/j.plaphy.2016.06.015

Vaculík, M., Mrázová, A., and Lux, A. (2015). Antimony (SbIII) reduces growth, declines photosynthesis, and modifies leaf tissue anatomy in sunflower (Helianthus annuus L.). Environ. Sci. Pollut. Res. Int. 22, 18699-18706. doi: 10.1007/s11356-015-5069-3

Wang, X. Q., He, M. C., Xie, J., Xi, J. H., Lu, X. F., Xu, J. M., et al. (2010). Heavy metal pollution of the world largest antimony mine-affected agricultural soils in hunan province (china). J. Soils Sediment 10, 827-837. doi: 10.1007/s11368010-0196-4

Wei, Y., Su, Q., Sun, Z. J., Shen, Y. Q., Li, J. N., Zhu, X. L., et al. (2016). The role of arbuscular mycorrhizal fungi in plant uptake, fractions, and speciation of antimony. Appl. Soil Ecol. 107, 244-250. doi: 10.1016/j.apsoil.2016.04.021

Wu, B. J., Chow, W. S., Liu, Y. J., Lei, S., and Jiang, C. D. (2014). Effects of stomatal development on stomatal conductance and on stomatal limitation of photosynthesis in syringa oblata and euonymus japonicus thunb. Plant Sci. 229, 23-31. doi: 10.1016/j.plantsci.2014.08.009

Zhang, Q., Liu, F., Ji, L., Yao, H., Ma, Y. F., and Zhang, X. Y. (2017). Effects of antimony stress on the biomass, photosynthetic characteristics and antimony accumulation of maize. J. Nuclear Agric. Sci. 31, 1633-1639.

Zhang, Y. L., Du, J. Z., Zhang, F. F., Yu, Y. H., and Zhang, J. (2011). Chemical characterization of humic substances isolated from mangrove swamp sediments: the qinglan area of hainan island, china. Estuar. Coast. Shelf. Sci. 93, 220-227. doi: 10.1016/j.ecss.2010.12.025

Conflict of Interest Statement: The authors declare that the research was conducted in the absence of any commercial or financial relationships that could be construed as a potential conflict of interest.

The reviewer OS and handling Editor declared their shared affiliation.

Copyright (c) 2018 Zhou, Sun, Zhu and Liu. This is an open-access article distributed under the terms of the Creative Commons Attribution License (CC BY). The use, distribution or reproduction in other forums is permitted, provided the original author(s) and the copyright owner are credited and that the original publication in this journal is cited, in accordance with accepted academic practice. No use, distribution or reproduction is permitted which does not comply with these terms. 